\title{
OXIDATIVE STABILITY OF A COLOMBIAN CRIOLLO MANGO (Mangifera Indica) DRINK FORTIFIED WITH PEEL
}

\author{
ESTABILIDAD OXIDATIVA DE UNA BEBIDA DE MANGO CRIOLLO COLOMBIANO \\ (Mangifera Indica) FORTIFICADA CON CÁSCARA
}

\begin{abstract}
Marcela MORALES S. ${ }^{\star \star}$, Karol ZAPATA A. ${ }^{2}$, Andrés Felipe ALZATE A. ${ }^{1}$, Alberto Antonio ANGULO. ${ }^{3}$, Benjamín ROJANO ${ }^{1}$
\end{abstract}

Received: March 26 of 2019. Approved: August 26 of 2019.

\begin{abstract}
Background: the analysis of the oxidative stability allows to determine the functionality of the antioxidants present in food, over time. Objectives: in this research, a functional mango drink is elaborated and the changes in the antioxidant profile and physicochemical parameters of the drink subjected to accelerated storage conditions are evaluated. Methods: the drink was distributed at 22,35 and $45^{\circ} \mathrm{C}$ for 80 days. To monitor oxidative stability, the antioxidant analyzes ABTS, ORAC, mangiferin, total phenols and total carotenoids were performed; in addition, physicochemical properties ( $\mathrm{pH}$ and ${ }^{\circ} \mathrm{Bx}$ ) and $\mathrm{L}^{\star} \mathrm{a}^{\star} \mathrm{b}^{\star}$ coordinates, were monitored. The fit of the data to the Arrhenius model was verified and the shelf life was determined considering a $50 \%$ loss in the evaluated attributes, such as the critical limit. Results: the deterioration of the antioxidant attributes and the color at the study temperatures is observed, being more pronounced at $45^{\circ} \mathrm{C}$. The least stable attributes are the carotenoids and the b-coordinate, presenting losses greater than $50 \%$. The values of mangiferin exhibit deterioration lower than $40 \%$ and similar in the temperatures evaluated. The $\mathrm{pH}$ and Brix degrees do not show significant changes. The deterioration reactions are of order one and followed the Arrhenius law, presenting coefficients of determination greater than 0.90 . The values of the activation energy (Ea) are within the range reported for fruit juices, standing out the value found for the $\mathrm{b}^{\star}$ coordinate $\left(44.59 \mathrm{~kJ} \cdot \mathrm{mol}^{-1}\right)$. Conclusions: the ORAC units are the chosen attribute to condition the life of the beverage, giving 10 months of useful life at $4^{\circ} \mathrm{C}$, however, it is recommended to perform sensory and microbiological analyzes under the same conditions.
\end{abstract}

Keywords: Functional drink, oxidative stability, peel, mango.

\section{RESUMEN}

Antecedentes: el análisis de la estabilidad oxidativa permite determinar la funcionalidad de los antioxidantes presentes en los alimentos, en el tiempo. Objetivo: en esta investigación se elaboró una bebida funcional de mango y se evaluaron los cambios en el perfil antioxidante y los parámetros fisicoquímicos de la bebida sometida a condiciones aceleradas de almacenamiento. Métodos: la bebida se distribuyó a 22, 35 y $45^{\circ} \mathrm{C}$ durante 80 días. Para hacer el seguimiento de la estabilidad oxidativa, se realizaron los análisis antioxidantes ABTS, ORAC, Mangiferina, Fenoles Totales y Carotenoides totales; además, se realizó seguimiento de las propiedades fisicoquímicas $\left(\mathrm{pH}\right.$ y $\left.{ }^{\circ} \mathrm{Bx}\right)$ y las coordenadas $\mathrm{L}^{\star} \mathrm{a}^{\star} \mathrm{b}^{\star}$. Se verificó el ajuste

\footnotetext{
$1 \quad$ Laboratorio de Ciencias de los Alimentos. Facultad de Ciencias, Universidad Nacional de Colombia. Medellín, Colombia

Facultad de Minas, Departamento de procesos y Energía, Universidad Nacional de Colombia. Medellín, Colombia

Universidad de Córdoba, Colombia

* Author of correspondence: dimmoralessav@unal.edu.co
} 
de los datos al modelo de Arrhenius y la vida útil se determinó teniendo en cuenta una pérdida del 50\% en los atributos evaluados, como el límite crítico. Resultados: se observó el deterioro de los atributos antioxidantes y el color en las temperaturas de estudio, siendo más pronunciado a $45^{\circ} \mathrm{C}$. Los atributos menos estables fueron carotenoides y la coordenada CIELab b夫, presentando pérdidas superiores al $50 \%$. Los valores de mangiferina exhibieron un deterioro menor al $40 \%$ y similar en las temperaturas evaluadas. El pH y los grados Brix no presentaron cambios significativos. Las reacciones de deterioro fueron de orden uno y siguieron la ley de Arrhenius, presentando coeficientes de determinación mayores a 0,90. Los valores de la energía de activación $(E a)$ estuvieron dentro del rango reportado para jugos de fruta, destacándose el valor hallado para la coordenada $b^{\star}\left(44,59 \mathrm{~kJ} \cdot \mathrm{mol}^{-1}\right)$. Conclusión: los valores ORAC estimaron un tiempo de vida útil para la bebida en 10 meses, bajo un almacenamiento a $4^{\circ} \mathrm{C}$, sin embargo, se recomienda realizar análisis sensoriales y microbiológicos complementarios, bajo las mismas condiciones.

Palabras clave: bebida funcional, estabilidad oxidativa, cáscara, mango.

\section{INTRODUCTION}

The mango (Mangifera Indica L.), the most important fruit in the Anacardiaceae family, has been well documented as an important source of micronutrients, vitamins and other phytochemicals. Moreover, mango fruits provide energy, dietary fibre, carbohydrates, proteins, fats and phenolic compounds (1), which are vital to normal human growth, development and health. Among the bioactive compounds found, the most important are flavonols, carotenoids and xanthones, with recognized positive health effects, associated to their capacity antioxidant (2). This fruit is the third tropical fruit worldwide in terms of its production and importance. In Colombia, there are approximately 23000 cultivated hectares, with more than 82 local varieties (3).

In recent years, the demand for food with a functional appeal has increased due to the presence of these bioactive compounds capable of promoting health and improving the quality of life of consumers (4). Within this type of food, functional drinks are widely accepted and distributed worldwide $(5,6)$. In relation to the thing before, different authors have reported that byproducts of fruit and vegetable processing, such as peel and seed, are a rich source of bioactive compounds that can be used as antioxidants and functional agents $(7,8)$. The mango peel is a byproduct rich in phytochemicals with antioxidant capacity, which has aroused great technological interest for its various applications in the industry $(9,10)$; however, the transformations that are made to the mango fruit are fundamentally from fresh pulp or reconstituted dehydrated pulp, evidencing that the peel is not included mostly in the processing (11). Due to above, it is important to determine the oxidative stability of the finished product and, consequently, its shelf life. For this, accelerated storage methods have become a very useful tool, especially those that accelerate deterioration due to temperature, based on compliance of the Arrhenius law (12).

According to the context proposed, this research developed a functional drink, fortifying a mango Criollo juice with lyophilized peel of the fruit and evaluated the oxidative stability of the finished product under accelerated storage conditions.

\section{MATERIALS AND METHODS}

\section{Materials and formulation}

Mangoes of the Criollo variety were selected according to their physical condition, without deterioration or blows for subsequent disinfection and pulping. The pulp and husk were lyophilized and pulverized, separately. A batch of functional mango drink was prepared, using: pulp, peel, sugar, stabilizer, preservative, acidulant and water (47).

\section{Storage studies: physicochemical and antioxidant stability}

The drink was packed in $60 \mathrm{~mL}$ PET bottles, which were distributed at 22,35 and $45^{\circ} \mathrm{C}$, for 80 days. The antioxidant and physicochemical analysis were performed every 7 days. The $\mathrm{pH}$ was determined with a Metrohm potentiometer model 744 and the soluble solids were measured by refractometry, using a refractometer equipment (PAL-1, Atago ${ }^{\circledR}$, Japan). The color determination was carried out using a Minolta colorimeter (Minolta Co. Ltd., Osaka, Japan) on the basis of the CIELAB color system $\left(\mathrm{L}^{\star}, \mathrm{a}^{\star}, \mathrm{b}^{\star}\right)$, where $\mathrm{L}^{\star}$ refers to luminosity, and the coordinates $\mathrm{a}^{\star}$ and $\mathrm{b}^{\star}$ to the red and yellow tones, respectively (13). 
To determine the antioxidant profile the ABTS methodologies (14) and ORAC (15) were carried out and for the quantification of bioactive metabolites mangiferina (16), total carotenoids (17) and total phenols (18), were evaluated. The behavior presented by the coordinates $\mathrm{L}^{\star} \mathrm{a}^{\star} \mathrm{b}^{\star}$, the antioxidant activity (ABTS and ORAC), and the bioactive metabolites allowed the description of the oxidative stability of the product.

\section{Reaction velocity}

Reaction order

The rate of deterioration can be expressed as a change in the concentration of an attribute as a function of time. The basic equation 1 represents this loss:

$$
\frac{d B}{d t}=k(B)^{n} \quad(\text { Equation 1) }
$$

Where $B$ is the measured quality parameter, $t$ is time, $k$ is a velocity constant and $n$ is the factor called reaction order, which defines the rate of loss (or increase) of $B$ (19). And the procedure to perform the determination of $\mathrm{R}^{2}$ and $k$ was based on what was described by Labuza (20).

\section{Activation Energy and Q10}

The effect of the storage temperature on the reaction rate of the attributes studied was determined using the Arrhenius model (see Equation (2),

$$
k=A e^{\frac{-E_{a}}{R T}}
$$

(Equation 2)

Where $A, e, E_{a}, R, T, k$, are frequency factor or the Arrhenius constant $\left(\mathrm{dí}^{-1}\right)$, number of Euler, activation energy of each reaction $\left(\mathrm{J}^{\star} \mathrm{mol}^{-1}\right)$, universal gas constant $\left(8.3145 \mathrm{~J}^{\star}\right.$ mol- $\left.1^{\star} \mathrm{K}^{-1}\right)$, absolute temperature $(\mathrm{K})$, and reaction rate constant (días-1), respectively.

According to this equation, the $L n$ of the constants $k$ was plotted against the inverse of the corresponding temperature, and with the slope of the line obtained the kinetic parameter $E_{a}$ was found for each attribute.

Another measure of the sensitivity of a food to changes in temperature is called the $Q_{10}$ factor of the reaction (acceleration factor, dimensionless; Equation 3) (20):

$$
Q_{10}=\frac{k_{\left(T+10^{\circ} \mathrm{C}\right)}}{k_{T^{\circ} \mathrm{C}}}
$$

(Equation 3)
Where: $\mathrm{T}$ and $\mathrm{T}+10^{\circ} \mathrm{C}$ are temperatures at which the shelf life is evaluated.

\section{Shelf life}

The shelf life was calculated by the deterioration of the antioxidant capacity during 80 days at the study temperatures and under refrigeration conditions $\left(4^{\circ} \mathrm{C}\right)$. In this work the critical limits $L_{c}$ were established as those in which the drink reaches $50 \%$ of the initial values $\left(V_{i}\right)$.

\section{Statistic analysis}

All the experiments were performed in triplicate. The regressions were calculated with a level of significance of $95 \%(p<0.05)$, using the Statgraphics Centurion XVI program.

\section{RESULTS}

The behavior observed in the antioxidant parameters and the color was similar, therefore, the graphs and tables show the representative results of some of them.

\section{Initial physicochemical and antioxidant profile}

The final beverage had a $\mathrm{pH}$ of 3.3 and a soluble solids content of $13.5^{\circ} \mathrm{Bx}$. Color was determined at through the coordinates $L^{\star} a^{\star} b$, which had values of 48, 23 and 52, respectively.

On the other hand, the drink presented an important content of antioxidant metabolites $(142.54 \mathrm{mg}$ mangiferina, $1438.5 \pm 52.9 \mathrm{mg}$ GAE and $4.41 \pm 0.01 \mathrm{mg} \beta$-carotene Eq) and a considerable activity $(8117.7 \pm 474.5$ and 5089.4 $\pm 213.0 \mu \mathrm{mol}$ trolox Eq in ABTS and ORAC, respectively).

\section{Storage studies: physicochemical and antioxidant stability}

The soluble solids $\left({ }^{\circ} \mathrm{Bx}\right)$ and the $\mathrm{pH}$, did not present changes in the time, nor significant differences inside and between the temperatures $(p>0.05)$, during the storage to accelerated conditions.

On the other hand, Figure 1 shows the degradation kinetics of the bioactive content (phenols and carotenoids), the antioxidant profile (ORAC) and the color $\left(b^{\star}\right)$ during the 90 days of the study. In Figure 2 the adjustment of the experimental data to the kinetic model of Arrhenius 
is presented. It was observed in all behaviors that the antioxidant parameters and color decreased over time and that the deterioration intensified at $45^{\circ} \mathrm{C}$, although there was significant differences within and between all temperatures $(\mathrm{p}<0.05)$ evaluated in each attribute, except for the coordinate $\mathrm{a}^{\star}$ and the metabolite mangiferina.

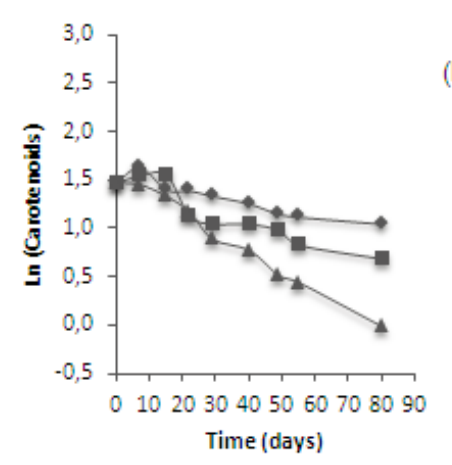

(B)

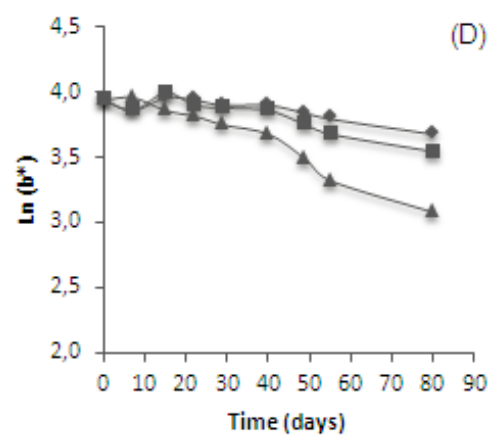

Figure 1. Behavior of order 1 of the bioactive compounds, the antioxidant activity and the coordinate $\mathrm{b}^{\star} .22^{\circ} \mathrm{C}$ (•) $35^{\circ} \mathrm{C}(\mathbf{\bullet}) 45^{\circ} \mathrm{C}(\boldsymbol{\Delta})$.
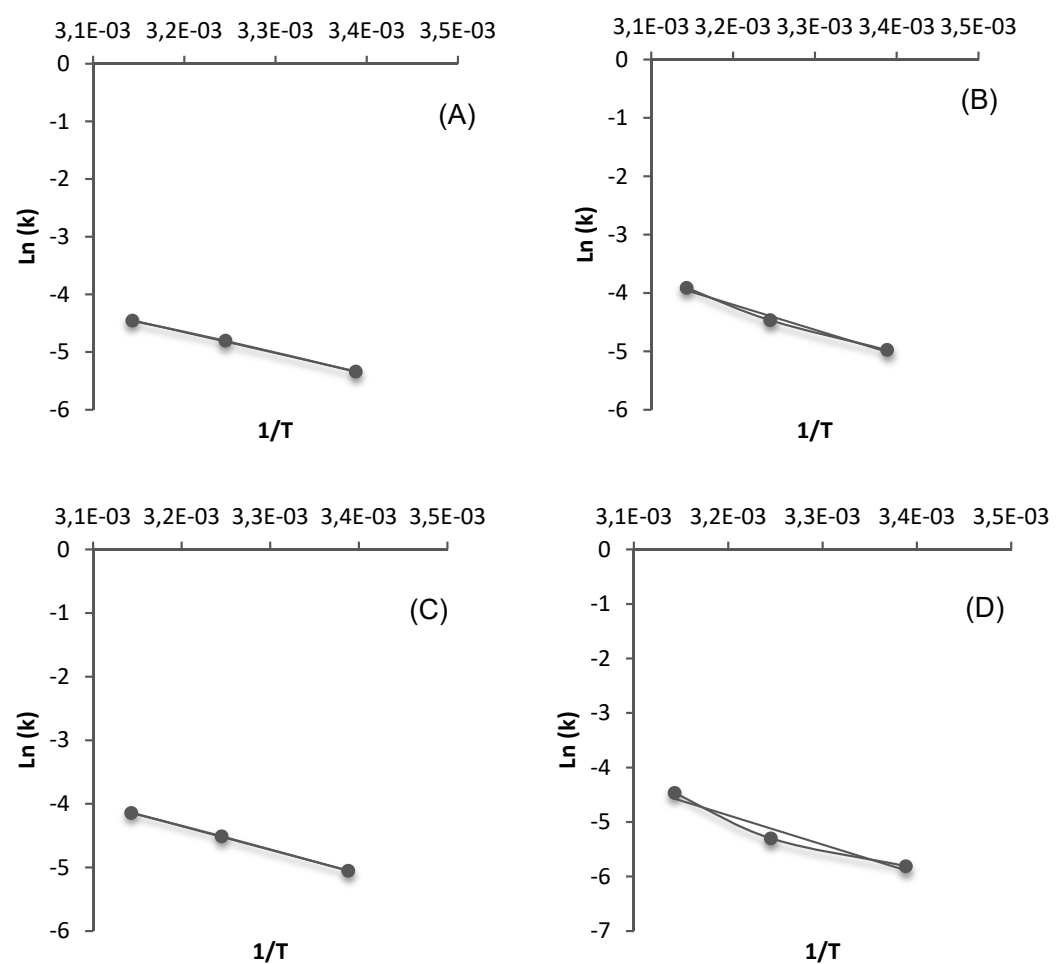

Figure 2. Adjustment to the Arrhenius kinetic model of total phenols (A), total carotenoids (B), ORAC (C) and coordinate $b^{\star}(D)$. 


\section{Reaction order}

Table 1 shows some of the determination coefficients obtained for each reaction order at the study temperatures. Although the differences in the coefficients are low, the reaction kinetics of the different attributes was of order one because of slightly higher $\mathrm{R}^{2}$ values.

Table 1. Coefficient of determination in the attributes evaluated in the functional drink.

\begin{tabular}{|l|c|c|c|}
\hline \multirow{2}{*}{ Attribute } & \multirow{2}{*}{ Temperature $\left({ }^{\circ} \mathbf{C}\right)$} & \multicolumn{2}{|c|}{$\boldsymbol{R}^{\mathbf{2}}$} \\
\cline { 2 - 4 } & & Zero order & Order one \\
\hline \multirow{3}{*}{ Total phenols } & 22 & 0.9308 & 0.9588 \\
\cline { 2 - 4 } & 35 & 0.8880 & 0.9232 \\
\cline { 2 - 4 } & 45 & 0.8230 & 0.8885 \\
\hline \multirow{3}{*}{$\begin{array}{l}\text { Total } \\
\text { carotenoids }\end{array}$} & 22 & 0.8194 & 0.8747 \\
\cline { 2 - 4 } & 35 & 0.7957 & 0.8667 \\
\hline \multirow{3}{*}{ ORAC } & 45 & 0.9365 & 0.9856 \\
\cline { 2 - 4 } & 22 & 0.7103 & 0.7536 \\
\cline { 2 - 4 } & 35 & 0.8766 & 0.8991 \\
\hline \multirow{3}{*}{$\mathbf{b}^{\star}$} & 45 & 0.9130 & 0.9427 \\
\cline { 2 - 4 } & 22 & 0.7244 & 0.7282 \\
\cline { 2 - 4 } & 35 & 0.8128 & 0.8238 \\
\hline
\end{tabular}

\section{Dependence of temperature on the rate of deterioration}

With linearized Equation 1, the constants of velocity $k$ (days-1) were determined in each attribute. Then, the values of $Q_{10}$ were calculated according to Equation 3, the determination coefficients and the activation energy $E_{a}$ were determined according to Equation 2. The results obtained are summarized in Table 2.

\section{Shelf life}

In the present work, the useful life was estimated as the period of time in which there is a $50 \%$ loss in the initial antioxidant attributes $(21,22)$. On the other hand, the legislation established that refrigerated foods, such as fruit juices, should be stored at temperatures no higher than $4^{\circ} \mathrm{C}$, although each food requires own conditions of temperature, humidity, lighting and ventilation (49).

So, the shelf life of the attributes was extrapolated to $4^{\circ} \mathrm{C}$. For this, the $L n$ of the $V . U$ obtained at the three study temperatures was plotted and then, from the line obtained, the linear equation was found, with which the shelf life at the refrigeration temperature was estimated, procedure performed for each attribute.

The shelf life at the different temperatures, for the critical limits established in each parameter, is summarized in Table 3.

Table 3. Shelf life (days) in each attribute at 4, 22, 35, $45^{\circ} \mathrm{C}$.

\begin{tabular}{|c|c|c|c|c|}
\hline \multirow{2}{*}{$\begin{array}{c}\text { Storage } \\
\text { temperature }\left({ }^{\circ} \mathbf{C}\right)\end{array}$} & \multicolumn{4}{|c|}{ Shelf life (days) } \\
\cline { 2 - 5 } & $\begin{array}{c}\text { Total } \\
\text { phenols }\end{array}$ & $\begin{array}{c}\text { Total } \\
\text { carotenoids }\end{array}$ & ABTS & ORAC \\
\hline 4 & 280 & 254 & 265 & 296 \\
\hline 22 & 134 & 110 & 142 & 136 \\
\hline 35 & 76 & 64 & 91 & 81 \\
\hline 45 & 52 & 38 & 64 & 51 \\
\hline
\end{tabular}

The results show that, at a higher temperature, a shorter shelf life time was obtained in all cases.

Table 2. Reaction rate constants, coefficients of determination $\left(\mathrm{R}^{2}\right)$ of the Arrhenius type equations, activation energies and values of $Q_{10}$ for the degradation of some attributes evaluated in the functional drink.

\begin{tabular}{|c|c|c|c|c|c|}
\hline Attribute & Temperature $\left({ }^{\circ} \mathrm{C}\right)$ & $k\left(\right.$ días $\left.^{-1}\right)$ & $R^{2}$ & Ea $(\mathrm{kJ} / \mathrm{mol})$ & $\mathrm{Q}_{10}$ \\
\hline \multirow{3}{*}{ Total phenols (Figure 2A) } & 22 & 0.0048 & \multirow{3}{*}{0.9993} & \multirow{3}{*}{30.03} & \multirow{3}{*}{1.41} \\
\hline & 35 & 0.0082 & & & \\
\hline & 45 & 0.0116 & & & \\
\hline \multirow{3}{*}{ Total carotenoids (Figure 2B) } & 22 & 0.0069 & \multirow{3}{*}{0.9858} & \multirow{3}{*}{35.71} & \multirow{3}{*}{1.74} \\
\hline & 35 & 0.0115 & & & \\
\hline & 45 & 0.0200 & & & \\
\hline \multirow{3}{*}{ ORAC (Figure 2C) } & 22 & 0.0064 & \multirow{3}{*}{0.9998} & \multirow{3}{*}{30.93} & \multirow{3}{*}{1.45} \\
\hline & 35 & 0.0110 & & & \\
\hline & 45 & 0.0159 & & & \\
\hline \multirow{3}{*}{$b^{\star}$ (Figure 2D) } & 22 & 0.0030 & \multirow{3}{*}{0.9464} & \multirow{3}{*}{44.59} & \multirow{3}{*}{2.30} \\
\hline & 35 & 0.0050 & & & \\
\hline & 45 & 0.0115 & & & \\
\hline
\end{tabular}

Note: The constants $k$ had a negative sign since they were reactions of decrease of the attribute, however, their values are reported as the absolute value. 
It is observed that at $4^{\circ} \mathrm{C}$ the antioxidant parameters presented a similar shelf life time. However, to condition the shelf life of the mango functional drink, the ORAC units were chosen as the limiting attribute, because this methodology is the most sensitive to the net content of antioxidants and is also widely accepted as a quality parameter. Therefore, the functional mango drink would have a shelf life of 296 days ( 10 months) at $4^{\circ} \mathrm{C}$, under the packing and processing conditions that took place in this investigation.

\section{DISCUSSION}

\section{Initial physicochemical and antioxidant profile}

The values of $\mathrm{pH}$ and ${ }^{\circ} \mathrm{Bx}$ were within the limits established by legislation (48). Followed this, color is considered a fundamental physical property of food products due to its correlation with other physicochemical and sensory indicators (23). The high value of the coordinate $\mathrm{a}^{\star}$ was associated with the use of the dye that gave reddish tones in the drink; the high value of the $b^{\star}$ coordinate was correlated with the presence of carotenoids, and the luminosity value $L^{\star}$ (ability to reflect or transmit light) was lower than the value reported in some mango drinks (24) and superior to that found in mango nectar (25). The differences between the $L^{\star} a^{\star} b^{\star}$ coordinates of the drink with other mango juices were associated with the addition of the peel, which affected the natural color of a conventional mango juice.

As for the antioxidant profile, according to Seeram et al. (2008) who compared the antioxidant potential of beverages in the polyphenols consumed in the United States, the beverage in this study the antioxidant activity and the total phenolic content similar to cranberry drinks, green iced tea and black iced tea, and mayor to what was reported for orange juice and apple juice (26). The carotenoid content was similar to that reported by CastroLópez et al. (2016) in functional drinks containing mango (27). Schulze et al. (2015) evaluated the content of mangiferin in the tea of different herbs that contributed to the dietary intake of mangiferin (28). The authors found $102 \mathrm{mg}$ mangiferin/L in the tea with the highest content, a result that was lower than that found in the present study. In general, the drink elaborated in this research could be classified as a drink rich in polyphenols and carotenoids, and with a greater antioxidant capacity compared to a conventional mango juice (29) and with other beverages cataloged as such.

\section{Storage studies: physicochemical and antioxidant stability}

The behavior observed in the $\mathrm{pH}$ and the soluble solids coincides with that reported by several authors when evaluating the stability of these in fruit juices subjected to different temperatures (30).

Oxidative stability of total phenols

Total phenols are the main metabolites responsible for antioxidant activity. Figure 1A shows the degradation of the phenolic compounds in the mango drink. It was observed an evidence of a greater reduction at $45^{\circ} \mathrm{C}$, in which the content was reduced by $59 \%$ compared to the reduction of 34 and $47 \%$ at 22 and $35^{\circ} \mathrm{C}$, respectively. Aishah et al. (2016) reported a $45 \%$ reduction in the phenols of guava juice stored at $50^{\circ} \mathrm{C}$ for 14 days (22). Siah et al. (2011) reported a $49 \%$ loss in the content of total phenols evaluated in a drink of Centella asiatica stored at $27^{\circ} \mathrm{C}$ for 2 months (31). This allows to infer that, in the mango drink, the polyphenols were stable, despite the observed decrease. However, the methodology used to measure said compounds is susceptible to other reducers such as amino acids, sugars, and / or compounds that are formed as a result of browning. In this way, false positives can be obtained with respect to the real content of total phenols, because the mango has been reported as a fruit with high reducing sugar content (25).

\section{Oxidative Stability of Total Carotenoids}

Carotenoids are important biological compounds found mainly in yellow or orange fruits and vegetables ( $\beta$-carotene, $\alpha$-carotene and cryptoxanthin), dark green color (lutein), and red color (lycopene). Some, such as lycopene and $\beta$-carotene, are credited with reducing the risk of contracting diseases such as cancer (32). As seen in Figure $1 \mathrm{~B}$, the carotenoids deteriorated during the study time, decreasing $34.5 \%, 54.6 \%$ and $77.4 \%$ at 22,35 and $45^{\circ} \mathrm{C}$, respectively. Lin and Chen (2005) evaluated the stability of carotenoids in tomato juice during 90 days of storage, reporting that $\beta$-carotene deteriorated $72 \%$ and $92 \%$ at $25^{\circ} \mathrm{C}$ and $35^{\circ} \mathrm{C}$, correspondingly (33). On the other hand, Manayay and Ibarz (2010) found that the brown compounds formed by the browning reactions that 
occurred in concentrated fruit juices presented a maximum absorbance at $420 \mathrm{~nm}$ (34). This explains that, although considerable deterioration occurred in the carotenoids of the mango drink, it was not as high as in other reports, because the extraction with acetone could drag interfering compounds that were manifested in the absorbance value.

\section{Oxidative stability mangiferina}

Mangiferin is a polyphenol with a C-glycosylxanthone structure found mainly in mango (Mangifera indica L.). It has been reported in a wide range of biological actions, within which its gastroprotective and antibacterial effect can be highlighted (35). This biological potential has been attributed, fundamentally, to its antioxidant properties (36). The deterioration of mangiferin during the study time was $26.7 \%, 30.0 \%$ and $33.8 \%$ at 22,35 and $45^{\circ} \mathrm{C}$, respectively. What the evidence that the deterioration was the same in the three temperatures evaluated $(\mathrm{p}>0.05)$ (Data not revealed). Beelders et al. (2017) mentioned differences in thermal stability of the compounds are related to their chemical structures, for example, xanthones (mangiferin and isomangiferin) were up to 10 times more stable compared to hydroxylated benzophenones, when these they were subjected to high temperatures (37). On the other hand, Beelders et al. (2018) modeled the degradation kinetics of mangiferin in a solution as a function of $\mathrm{pH}$ and temperature. They found that temperature dependence was adequately described by the Arrhenius equation when assessing the deterioration of xanthone between 60 and $140^{\circ} \mathrm{C}$, because in this range a significant increase in reaction rate constants could be seen (38). According to the above, the minimum differences found in the mangiferin content of the mango drink between and within the temperatures evaluated in this study would be explained.

\section{Oxidative stability of antioxidant activity (ABTS and ORAC)}

Selected assays to measure antioxidant activity are indicators of SET (Single Electron Transfer) and HAT (Hydrogen Atom Transfer) mechanisms involved in the oxidative process. In Figure 1C, the decay of the antioxidant activity measured through ORAC units is observed, behavior that was also observed in ABTS. At $22^{\circ} \mathrm{C}$ they decreased 37.6 and $31.9 \%$, at $35^{\circ} \mathrm{C}$ they dropped 50.3 and $52.7 \%$, and at $45^{\circ} \mathrm{C}$ the percentages of deterioration were 61.0 and $65.2 \%$, for ABTS and ORAC, respectively. In another study, it was reported that the antioxidant activity of the Centella asiatica drink stored 3 months at $27^{\circ} \mathrm{C}$, decreased by $47.4 \%$ (31), similar to that found in this work. The decrease in the ABTS and ORAC methodologies was associated with the deterioration of antioxidant metabolites present in the drink (polyphenols and carotenoids).

Stability of the color measured through the coordinates $L^{\star} a^{\star} b^{\star}$

Darkening in fruit juices is the most common quality problem that involves the loss of nutrients and the formation of undesirable intermediates (39). The decrease presented by the coordinate $L^{\star}$ refers to the loss of luminescence (closer to black) and in $b^{\star}$ to the decrease in yellow tones. In contrast, the colorimetric parameter $\mathrm{a}^{\star}$ did not show significant changes $(p>0.05)$, which coincides with different studies where they evaluated the stability of the mango pulp at elevated temperature conditions, and found that the coordinate to $\mathrm{a}^{\star}$ was the most stable, reporting greater variations above $85^{\circ} \mathrm{C}$ (40). To explain the appearance of the observed darkening, it should be mentioned that the thermal treatment, the addition of citric acid and, therefore, the low $\mathrm{pH}$ (similar to the $\mathrm{pH}$ of an orange juice) could inhibit the action of the enzyme polyphenol oxidase following that reported by Garzón et al., (2012) (41); therefore, non-enzymatic browning could be considered as the main chemical reaction responsible for the loss of color (39).

\section{Reaction order}

The deterioration of order one means an exponential decay in the speed of the loss of the quality factor, that is to say that it increases or decreases more and more rapidly over time. The results obtained in this study for all parameters were within the reported, because first-order kinetics is the most common to describe the loss of quality attributes such as antioxidants and vitamins (42). However, both zero-order and first-order kinetics have been associated with nonenzymatic browning reactions, lipid oxidation and enzymatic degradation $(39,42)$. 


\section{Dependence of temperature on the rate of deterioration}

Since there are few reports regarding the reaction rate constants for the evaluated antioxidant attributes, their values were compared with those reported for constants of deterioration of ascorbic acid, which has been considered a parameter of oxidation widely studied. Burdurlu et al., (2006) reported a range of 0.029 and 0.036 days $^{-1}$ for the constants of degradation rate of ascorbic acid at $45^{\circ} \mathrm{C}$ in different fruit juices, values that exceed those found in this investigation (50). In other studies, higher values of $k$ were also found with respect to those reported in this study $(21 ; 43)$. In the case of the carotenoids and the coordinates $\mathrm{L}^{\star}$ and $\mathrm{b}$ *, the constants $\mathrm{k}$ were within the range reported in mango juice and other foods (44).

It should be noted that, in all cases, the reaction rate constant increased with temperature, which is consistent because the speed of deterioration is accelerated by its increase.

On the other hand, the results indicated that the dependence of the velocity constants with the temperature followed the Arrhenius relation presenting coefficients of determination $R^{2}$ greater than 0.90 , except for the coordinate $L^{\star}$, whose coefficient was 0.8281 . Selen et al. studied the effect of storage on the non-enzymatic browning of apple juice. They found that the $\mathrm{L}^{\star}$ coordinate did not show significant changes at 5 and $20^{\circ} \mathrm{C}$ during 4 months of study, however, at 50 and $65^{\circ} \mathrm{C}$ they observed that there was a marked decrease in the $L^{\star}$ parameter (45). These results would explain that, under the temperature range evaluated in this study, a low linear adjustment of the $\mathrm{L}^{\star}$ coordinate has been found.

The activation energy of chemical reactions in food is usually within the range of $24-150 \mathrm{~kJ} \cdot \mathrm{mol}^{-1}$ (46). High values $E_{a}$ of $\left(>65 \mathrm{~kJ} \cdot \mathrm{mol}^{-1}\right)$ indicate a high susceptibility of the attribute to deterioration in the face of an increase in temperature. Touati et al., (2016) reported similar values of $E_{a}$ for carotenoids and ORAC in different fruit juices evaluated between $4-37^{\circ} \mathrm{C}$ (45); Aishah et al., (2016) reported $14.11 \mathrm{~kJ} \cdot \mathrm{mol}^{-1}$ as the activation energy for total phenols in pink guava juice evaluated between $40-50^{\circ} \mathrm{C}(22)$; and Oliveira et al., (2012) found $74.06 \mathrm{~kJ} \cdot \mathrm{mol}^{-1}$ for the $\mathrm{b}^{\star}$ coordinate during storage of mango juice between $25-45^{\circ} \mathrm{C}$ (46). According to the above, the activation energy values of this study (Table 2) are within what is reported in the literature. The attribute that showed the highest sensitivity with respect to the increase in temperature was the $\mathrm{b}^{\star}$ coordinate, behavior that is consistent with the deterioration observed in the carotenoids, the main metabolites responsible for yellow coloration (46). However, the differences that occur between the various values of $E_{a}$ reported are due to the fact that this parameter depends on several factors such as the food matrix, temperature, solids concentration, water activity, among others (19).

Labuza (1985) indicated that an option to express the dependence of the temperature that has been widely used by the industry is the concept of $Q_{10}$ (18). It is defined how the change of useful life, that is, the time necessary for the attribute to reach unacceptable levels, when the food is stored at a temperature $10^{\circ} \mathrm{C}$ higher. The value of $Q_{10}$ in total phenols, for example, means that the rate of deterioration would accelerate 1.41 times per $10^{\circ} \mathrm{C}$ that increase in temperature, and in the same way would apply to each attribute. The highest result was found in the $b^{\star}$ coordinate, which coincides with the behavior found for the activation energy. Although the magnitude of $Q_{10}$ depends on the type of food and the absolute range, the values found in this research are within what is reported in mango juice, guava juice and other fruits for the same temperature range (22).

\section{Shelf life}

Labuza (1982) indicates that the shelf life of a food is the time it will retain an acceptable level of food quality from the point of view of safety and sensory aspects. This period depends on four essential factors: knowing the formulation, processing, packaging and storage conditions (19).

The shelf life of a commercial fruit juice without aseptic packaging, under refrigeration conditions, is approximately 5 months. In this case, a longer time than expected was obtained. This is due to the fact that the parameters that affect the shelf life of the food are directly related to the microbial and chemical quality of the products. Therefore, in addition to monitoring the functional attributes (antioxidant capacity), it is necessary to carry out a sensory and microbiological follow-up, thereby guaranteeing a period in which the drink retains its functionality, innocuousness and acceptance by the consumer. 


\section{CONCLUSION}

The metabolites (phenols, carotenoids and mangiferin) and antioxidant activity (ABTS and ORAC) deteriorated under the study conditions and at $45^{\circ} \mathrm{C}$ the greatest loss was observed. However, the changes observed in mangiferin were not significant. The browning that was observed in the drink, mainly at 35 and $45^{\circ} \mathrm{C}$, explained the decrease in color, measured through the coordinates $\mathrm{L}^{\star} \mathrm{a}^{\star} \mathrm{b} \star$, which coincides with the oxidative phenomena observed. The kinetics of deterioration in the evaluated attributes was fundamentally of order 1 and followed the Arrhenius equation presenting coefficients $\left(R^{2}\right)$ greater than 0.90 . The activation energy $\left(E_{a}\right)$ was found within the range reported for food and juices, finding the highest in the $b^{\star}$ coordinate. The shelf life of the drink was conditioned to the ORAC units, taking into account $50 \%$ of the initial value as a critical limit. Its value was 10 months under refrigeration conditions $\left(4^{\circ} \mathrm{C}\right)$, however, it is recommended to perform microbiological and sensory analyzes in future investigations.

\section{REFERENCES}

1. Jahurul M, Zaidul I, Ghafoor K, Al-Juhaimi F, Nyam K, Norulaini N, et al. Mango (Mangifera indica L.) by-products and their valuable components: A review. Food Chem. 2015; 183: 173-180, DOI: 10.1016/j.foodchem.2015.03.046.

2. Masibo M, He Q. Major mango polyphenols and their potential significance to human health. Compr Rev Food SCI F. 2008; 7:309-319, DOI: 10.1111/j.1541-4337.2008.00047.x.

3. Asohofrucol (Asociación Hortifrutícola de Colombia), Fondo Nacional de Fomento Hortifrutícola, Programa de transformación productiva "Sectores de clase mundial". (2013). Plan de Negocios para el Sector Hortofrutícola en Colombia. FASE V. Informe Final. Recuperado de: https:// www.ptp.com.co/documentos/Plan\%20de\%20negocio\%20 hortofrut\%C3\%ADcola.pdf

4. Chen, M. The joint moderating effect of health consciousness and healthy lifestyle on consumers' willingness to use functional foods in Taiwan. Appetite. 2011; 57: 253-262, DOI: 10.1016/j. appet.2011.05.305.

5. Seeram N.P, Aviram M, Zhang Y, Henning M, Feng L, Dreher M, Heber D. Comparison of Antioxidant Potency of Commonly Consumed Polyphenol-Rich Beverages in the United States Comparison of Antioxidant Potency of Commonly Consumed Polyphenol-Rich Beverages in the United. J Agr Food Chem. 2008; 56: 1415-1422, DOI: 10.1021/jf073035s.

6. Wootton-Beard P. C, Moran A, and Ryan L. Stability of the total antioxidant capacity and total polyphenol content of 23 commercially available vegetable juices before and after in vitro digestion measured by FRAP, DPPH, ABTS and Folin-Ciocalteu methods. Food Res Int. 2011; 44(1): 217-224, DOI: 10.1016/j. foodres.2010.10.033.

7. Alasalvar C, Karamac M, Kosinska A, Rybarczyk A, Shahidi F, Amarowicz R. Antioxidant Activity of Hazelnut Skin Phenolics. J. Agric. Food Chem. 2009; 57: 4645-4650, DOI: 10.1021/ jf900489d.
8. Ajila C.M, Aalami M, Leelavathi K, Prasada-Rao UJS. Mango peel powder: A potential source of antioxidant and dietary fiber in macaroni preparations. Innov. Food Sci. and Emerg. Technol. 2010; 11: 219-224, DOI:10.1016/j.ifset.2009.10.004.

9. Azuola R.Y, Vargas P. Extracción de sustancias asistidas por Ultrasonido. Tecnol. Marcha. 2007; 20(4): 31-32.

10. Serna-Cock L, Torres-León C, Ayala-Aponte A. Evaluación de polvos alimentarios obtenidos de cáscaras de mango (Mangifera indica) como fuente de ingredientes funcionales. Información Tecnológica. 2015; 26(2): 41-50, DOI: 10.4067/S071807642015000200006.

11. Márquez Cardozo C.J, Jiménez Castañeda CA, Salazar Ripoll C.S. Development of mango (Mangifera indica L.) energy drinks. Rev. Fac. Nac. Agron. 2017; 70(1): 8115, DOI: 10.15446/rfna. v70n1.61770.

12. Baik B.K, Ullrich S.E. Barley for food: characteristics, improvement and renewed interest. J Cereal SCI. 2008; 48(2): 233-242, DOI:10.1016/j.jcs.2008.02.002.

13. Rein M.J, Heinonen M. Stability and Enhancement of Berry Juice Color. J. Agric. Food Chem. 2004; 52(10): 3106-3114, DOI: 10.1021/jf035507i.

14. Re R, Pellegrini N, Proteggente A, Pannala A, Yang M, RiceEvans C. Antioxidant activity applying an improved ABTS radical cation decolorization assay. Free Radic Biol Med. 1999; 26(9-10), 1231-7.

15. Prior RL, Wu X, Schaich K. Standardized methods for the determination of antioxidant capacity and phenolics in foods and dietary supplements. J. Agric. Food Chem. 2005; 53(10): 4290-4302, DOI: 10.1021/jf0502698.

16. Biswas AK, Sahoo J, Chatli MK. A simple UV-Vis spectrophotometric method for determination of $\beta$-carotene content in raw carrot, sweet potato and supplemented chicken meat Nuggets. Food Sci. Technol. 2011; 44(8): 1809-1813, DOI: 10.1016/j.lwt.2011.03.017.

17. Singleton V.L, Rossi J.A. Colorimetry of total phenolics with phosphomolybdic-phosphotungstic acid reagents. Am J Enol Viticult. 1965; 16: 144-158.

18. Labuza TP \& Schmidl MK. Accelerated Shelf-Life Testing of Foods. Food Technol. 1985; 39: 57-64.

19. Labuza, TP. Shelf life dating of foods. Westport, Connecticut: Food \& Nutrition Press. 1982.

20. León Hancco J.G. Determinación de la vida útil del néctar de naranja estabilizado con proteina aislada de quinua (Chenopodium quínoa Willd). Universidad Nacional del Altiplano. 2010.

21. Polydera A.C, Stoforos N.G, Taoukis P.S. Quality degradation kinetics of pasteurised and high pressure processed fresh Navel orange juice: Nutritional parameters and shelf life. Innov. Food Sci. Emerg. Technol. 2005; 6(1): 1-9, DOI:10.1016/j. ifset.2004.10.004.

22. Aishah B, Hannah K, Zati Alyani O. Stability of selected quality attributes of pink guava juice during storage at elevated temperatures. INT FOOD RES J. 2016: 23(5): 1918-1925.

23. Segnini S, Dejmek P, Öste R. A low-cost video technique for color measurement of potato chips. J. Food Sci. Technol. 1999; 32: 216-222, DOI: 10.1006/fstl.1999.0536.

24. Zulueta A, Esteve M.J, Frígola A. Carotenoids and color of fruit juice and milk beverage mixtures. J. Food Sci. 2007; 72(9), DOI: 10.1111/j.1750-3841.2007.00550.x.

25. Kumar R, Bawa AS, Kathiravan T \& Nadanasabapathi S. Thermal processing of mango nectar (Mangifera indica) and its effect on chemical, microbiological and sensory quality characteristics. International. J. Adv. Res. 2013; 1(8): 261-273.

26. Seeram N.P, Aviram M, Zhang Y, Henning M, Feng L, Dreher M, Heber D. Comparison of Antioxidant Potency of Commonly Consumed Polyphenol-Rich Beverages in the United States Comparison of Antioxidant Potency of Commonly Consumed Polyphenol-Rich Beverages in the United. J. Agric. Food Chem. 2008; 56: 1415-1422, DOI: 10.1021/jf073035s. 
27. Castro-López C, Sánchez-Alejo E.J, Saucedo-Pompa S, Rojas R, Aranda-Ruiz J, Martínez-Avila GCG. Fluctuations in phenolic content, ascorbic acid and total carotenoids and antioxidant activity of fruit beverages during storage. Heliyon. 2016; 2(9), DOI: 10.1016/j.heliyon.2016.e00152.

28. Schulze AE, Beelders T, Koch I.S, Erasmus L.M, De Beer D, Joubert E. Honeybush herbal teas (Cyclopia spp.) contribute to high levels of dietary exposure to xanthones, benzophenones, dihydrochalcones and other bioactive phenolics. J. Food Compos. Anal. 2015; 44: 139-148, DOI: 10.1016/j.jfca.2015.08.002.

29. Santhirasegaram V, Razali Z \& Somasundram C. Effects of thermal treatment and sonication on quality attributes of Chokanan mango (Mangifera indica L.) juice. Ultrason. Sonochem. 2013; 20(5): 1276-1282, doi.org/10.1016/j.ultsonch.2013.02.005.

30. Kunitake M, Ditchfield C, Silva C, Petrus R. Effect of pasteurization temperature on stability of an acidified sugarcane juice beverage. Ciênc. Agrotec. 2014; 38(6): 554-561, DOI: 10.1590/S1413-70542014000600004.

31. Siah W.M, Faridah H, Rahimah MZ, Tahir SM \& Zain DM. Effects of packaging materials and storage on total phenolic content and antioxidant activity of Centella asiatica drinks. J. Trop. Agric. and Fd. Sc. 2011; 39(1): 1-7.

32. Rao AV, Rao L.G. Carotenoids and human health. Pharmacol Res. 2007; 55(3), 207-16, DOI : 10.1016/j.phrs.2007.01.012.

33. Lin C.H, Chen B.H. Stability of carotenoids in tomato juice during storage. Food Chem.2005; 90(4): 837-846, DOI: 10.1016/j.foodchem.2004.05.031.

34. Manayay D, Ibarz A. Modeling the kinetics non-enzymatic browning reactions and rheological behavior in the termal process of fruit juices and pulps. Sci. Agric. 2010; 1: 155-168, DOI: 10.17268/sci.agropecu.2010.02.06.

35. Duang X.Y, Wang Q, Zhou XD, Huang D.M. Mangiferin: a possible strategy for periodontal disease to therapy. Med Hypotheses. 2011; 76: 486-488, DOI: 10.1016/j.mehy.2010.11.029.

36. Ferreira F da R, Valentim I.B, Ramones ELC, Trevisan MTS, Olea-Azar C, Pérez-Cruz et al. Antioxidant activity of the mangiferin inclusion complex with $\beta$-cyclodextrin. Food Sci. Technol. 2013; 51(1), DOI: 10.1016/j.lwt.2012.09.032.

37. Beelders T, de Beer D, Ferreira D, Kidd M, Joubert E. Thermal stability of the functional ingredients, glucosylated benzophenones and xanthones of honeybush (Cyclopia genistoides), in an aqueous model solution. Food Chem. 2017; 233: 412-421, DOI: 10.1016/j.foodchem.2017.04.083.
38. Beelders T, de Beer D, Kidd M, Joubert E. Modeling of thermal degradation kinetics of the C-glucosyl xanthone mangiferin in an aqueous model solution as a function of $\mathrm{pH}$ and temperature and protective effect of honeybush extract matrix. Food Res Int. 2018; 103: 103-109, DOI: 10.1016/j.foodres.2017.10.020.

39. Bharate S.S, Bharate S.B. Non-enzymatic browning in citrus juice: chemical markers, their detection and ways to improve product quality. J. Food Sci. Technol 2012; 51(10): 2271-2288, DOI: 10.1007/s13197-012-0718-8.

40. Manayay D, Ibarz A, Castillo Martinez W, Palacios L. Cinética de la diferencia de color y croma en el proceso térmico de pulpa de mango (Mangifera indica L.) variedad. Sci. Agric. 2013; 4: 181190, DOI: 10.17268/sci.agropecu.2013.03.04.

41. Garzón MAG, Rojano BA \& Guerrero, CA. Inhibición de la polifenoloxidasa extraída del banano (cavendish) por medio de algunos derivados del isoespintanol. Corporación Universitaria Lasallista. 2012; 193-248. Retrieved from http://hdl.handle. net/10567/148.

42. Rajauria G, Tiwari B. Fruit Juices: Extraction, Composition, Quality and Analysis, Ireland, Dublin. Academic Press an imprint of Elsevier. 2017.

43. Sinchaipanit P, Ahmad M, Twichatwitayakul R. Kinetics of Ascorbic Acid Degradation and Quality Changes in Guava Juice during Refrigerated Storage. Food Nutr. Res. 2015; 3(8): 550-557, DOI: $10.12691 /$ jfnr-3-8-10.

44. Bechoff A, Chijioke U, Tomlins KI, Govinden P, Ilona P, Westby A, Boy E. Carotenoid stability during storage of yellow gari made from biofortified cassava or with palm oil. J Food Compos Anal. 2015; 44: 36-44, DOI: 10.1016/j.jfca.2015.06.002.

45. Touati N, Barba F.J, Louaileche H, Frigola A, Esteve M.J. Effect of Storage Time and Temperature on the Quality of Fruit Nectars: Determination of Nutritional Loss Indicators. J. Food Qual. 2016; 39: 209-217, DOI: 10.1111/jfq.12189.

46. Oliveira A do N, Ramos A.M, Minim VPR, Chaves JBP. Sensory stability of whole mango juice: influence of temperature and storage time. Food Sci. Technol. 2012; 32(4): 819-825.

47. Resolución 10593, Ministerio de Salud, Colombia.

48. Resolución 3929 de 2013 INVIMA.

49. Resolución 2674 de 2013, Ministerio de Salud y Protección Social de Colombia. 